\title{
First report on the occurrence of Trypanosoma rangeli Tejera, 1920 in the state of Ceará, Brazil, in naturally infected triatomine Rhodnius nasutus Stål, 1859 (Hemiptera, Reduviidae, Triatominae)
}

\author{
Fernando Braga Stehling Dias, Liléia Diotaiuti/+, Alvaro José Romanha ${ }^{*}$, Cláudia \\ Mendonça Bezerra** ${ }^{*}$, Evandro Marques de Menezes Machado
}

\begin{abstract}
Laboratório de Triatomíneos e Epidemiologia da Doença de Chagas *Laboratório de Parasitologia Celular e Molecular, Centro de Pesquisas René Rachou-Fiocruz, Av. Augusto de Lima 1715, 30190-002 Belo Horizonte, MG, Brasil ** Secretaria do Estado da Saúde do Ceará, Fortaleza, CE, Brasil
\end{abstract}

The aim of this work was to identify and report the occurrence of Trypanosoma rangeli and Trypanosoma cruzi in naturally infected Rhodnius nasutus (Hemiptera, Reduviidae, Triatominae) in the state of Ceará, Brazil. Triatomines feces, salivary glands, and hemolymph were collected for fresh examination, and specific detection of $\mathrm{T}$. rangeli and $\mathrm{T}$. cruzi DNA by polymerase chain reaction was carried out. The specific characterization of these two parasites showed the simultaneous presence of both parasites in two (7.7\%) of the 26 positive insects. Our results provide further knowledge on the geographical distribution of T. rangeli in Brazil.

Key words: Trypanosoma rangeli - Rhodnius nasutus - Ceará

Trypanosoma rangeli Tejera, 1920 and Trypanosoma cruzi Chagas, 1909, are hemoflagellate protozoa of the Family Trypanosomatidae, belonging to the Order Kinetoplastida (D'Alessandro 1976). Both parasites are sympatric in Americas with a wide geographic distribution. T. cruzi is the etiological agent of Chagas disease, and T. rangeli is responsible for a non-pathogenic infection in mammals (D'Alessandro \& Saraiva 1992). Both parasites can be found in the same triatomine vector species, and in the same vertebrate hosts, which are mammals belonging to different orders and genera, including humans (D'Alessandro \& Saraiva 1992). Although $T$. rangeli is not pathogenic for the vertebrate host, its occurrence should be recorded as it frequently presents an overlapping distribution with $T$. cruzi (D'Alessandro 1976). T. rangeli bears similarities with T. cruzi regarding surface antigens, impairing the diagnosis of Chagas disease when serological assays are carried out. Moreover, considering the fact that $T$. rangeli is highly pleomorphic, its morphological identification may be rather difficult, being misidentified as $T$. cruzi (Urdaneta-Morales \& Tejero 1992).

Interactions between $T$. rangeli and its invertebrate host starts after ingestion of trypomastigote forms during the triatomine blood feeding. Following ingestion, trypomastigotes undergo differentiation to epimastigotes that multiply in the insect vector intestine. After reaching the intestine lumen, the epimatigote forms invade hemocelle, in which they remain to multiply either

\footnotetext{
Financial support: Fapemig, CNPq, CPqRR-Fiocruz

+ Corresponding author: diotaiuti@cpqrr.fiocruz.br

Received 20 December 2006

Accepted 26 April 2007
}

inside or outside hemocytes and, then, they actively penetrate through salivary glands, especially in Rhodnius species, where metacyclogenesis occurs (D'Alessandro $\&$ Hincapie 1986). In vertebrate hosts, T. rangeli has been reported to infect more than 20 genera in five different animal orders (D'Alessandro \& Saraiva 1992). The vertebrate host infection occurs during the triatomine blood feeding, through which infective trypomastigotes are released together with the vector saliva (Vallejo et al. 1988).

In Brazil, the first report on the occurrence of $T$. rangeli was issued by Deane (1958) in Didelphis marsupialis, in the state of Pará. Steindel et al. (1991) reported the presence of T. rangeli in the rodent Echimys dasythrix in Southern Brazil. Several other reports on T. rangeli occurrence in Brazil have been given by some investigators such as those by Diotaiuti et al. (1992) who reported the occurrence of that flagellate, based on its morphology, in $R$. neglectus in the state of Tocantins; Lucena and Verguetti (1973) reported Panstrongylus megistus infections with the flagellate, also based on its morphological traits, in the state of Alagoas; in Bahia, Barrett and Oliveira (1977) reported natural infection of a $R$. domesticus nymph with $T$. rangeli; Ramirez et al. (2002) demonstrated $D$. albiventris infection with $T$. rangeli in the Southeast. A single report on human infection with $T$. rangeli was made by Coura et al. (1996) in the Amazon region, and $R$. brethesi may be considered the most likely vector in the region.

The current investigation was aimed at verifying the occurrence of $T$. rangeli in $R$. nasutus specimens collected on different palm tree species, namely: babaçu palm (Attalea speciosa); buriti (Mauritia flexuosa); carnaúba palm (Copernicia prunifera); catolé palm (Syagrus oleracea); and macaúba-barriguda (Acrocomia intumescens), in rural areas from five municipalities of Chapada do Araripe, in the southern region of Ceará, Brazil, between 14 March and 06 April, 2006. 
The insects were evaluated regarding the presence of trypanosome in their intestinal content through analyzing their fresh feces obtained by abdominal compression; hemolymph analysis on glass slides was also carried out after sectioning one of the insect legs. Salivary glands from positive hemolymph were dissected in order to verify the presence of parasites. All biological material obtained was analyzed under light microscopy (magnification $160 \mathrm{x}$ ). The trypanosomes were isolated from insects in LIT medium added to blood agar maintained at $27.5^{\circ} \mathrm{C}$, keeping weekly passages.

Polymerase chain reaction (PCR) has been known to be more sensitive than optical microscopy for detection and specific characterization of these trypanosomes in insect vectors, mainly concerning the possibility of mixed infection (Machado et al. 2000). Hence, we have used PCR for specific detection of T. rangeli and T. cruzi in samples of isolated parasites; DNA was obtained from parasite cultures using standard phenol/chloroform/ isoamyl alcohol extraction (Steindel et al. 1993). Detection of $T$. rangeli was based on amplification of an intergenic region of $T$. rangeli mini-exon with the following primers: TrINT-1 - 5'-CGC CCA TTC GTT TGT CC-3'; TrINT-2 - 5'-TCC AGC GCC ATC ACT GAT C-3'; and TrINT-3 - 5'-AAG ATG AGG CGT GGC TCT G-3' (Grisard et al. 1999). For T. cruzi detection, specific primers were designed to amplify an intergenic region of the mini-exon gene (Souto et al. 1996). As positive control, the $T$. rangeli San Agustin strain, isolated from a Colombian chagasic patient, was used. The products were submitted to electrophoresis in polyacrylamide gel and then revealed after being silver stained.

Out of the 26 insects positive for trypanosome in their intestines, two (7.7\%) showed to be positive for trypanosome in hemolymph without showing parasites in their salivary glands though. Molecular typing of isolated samples using TrINT primers showed to be specific for $T$. rangeli, amplifying a band of approximately $203 \mathrm{bp}$ and two other bands of less intensity, 244 and 265 bp, respectively, which provided corroborating evidence to our microscopic findings (Figure). In all isolates, T. cruzi was identified (data not shown), including the samples in which T. rangeli was isolated, which confirmed the presence of mixed infection.

In the present study, identification of Trypanosomatidae found in the insect intestine tract by means of morphological analysis was not possible, requiring a diagnosis confirmation through PCR. An overlapping geographic distribution of both $T$. cruzi and T. rangeli, occurrence of mixed infection in vertebrate and invertebrate hosts and, T. rangeli pleomorphism account for the need for molecular techniques for identification of Trypanosomatidae species. By using PCR, that enabled amplification of the intergenic region of the mini-exon gene, we were able to identify the Trypanosomatidae species in $R$. nasutus collected in the state of Ceará, Brazil. The present communication is the first to report the occurrence of $T$. rangeli in the state of Ceará, Brazil, identified in naturally infected triatomines of the species $R$. nasutus.

Chapada do Araripe is comprised in the mountain regions of the Brazilian semi-arid, regarded as remaining areas of humid forests in the caatinga vegetation. It presents typical elements of the Brazilian Amazon, Mata Atlântica and cerrado (Bagnoli 1998), what is validated through geologics, floristics, and faunistics evidences (Monteiro \& Kaz 1994). In regions with an overlapping of the geographic distribution of T. cruzi and T. rangeli, co-infections in vectors and vertebrates are common (D'Alessandro \& Saraiva 1992). The presence of marsupials in the palms, being this important reservoir of both parasites, may favour the occurrence of co-infection in the same insect, as suggested for other authors (Cuba-Cuba 1998, Ramirez et al. 2002), specially considering that blood of these animals in the stomachal content of infected triatomines was identified through the precipitin technique (data not shown).

The occurrence of $T$. rangeli in naturally infected $R$. nasutus from palm trees in Ceará provides further knowledge on the geographical distribution of this parasite in Brazil. Considering that in the Brazilian caatinga there are areas similar to the Chapada do Araripe (Cavalcante 2005), it is very likely that the occurrence of $T$. rangeli in triatomines colonizing palm trees in the Northeast,

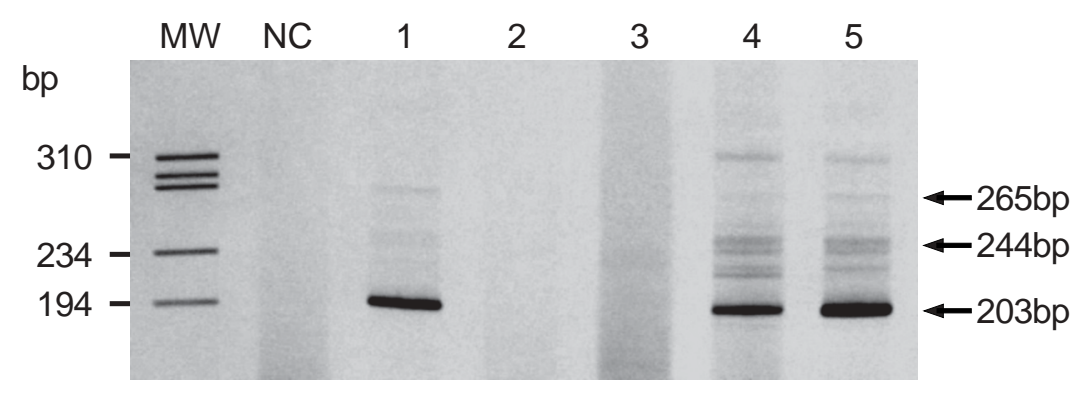

Polymerase chain reaction amplification products of the mini-exon gene generated by Trypanosoma samples isolated from naturally infected Rhodnius nasutus using the primers TrINT 1, TrINT 2, and TrINT 3. MW: molecular weight, the numbers on the left are the size markers ( $\phi$ X174 digested by the restriction enzyme Haell); NC: negative control (no DNA add). Lanes - 1: strain RN01; 2: RN02; 3: RN03; 4: RN04; 5: strain San Agustin (positive control), visualized on $8 \%$ polyacrilamide gel, silver stained. 
as well as associated with vertebrate hosts, may be even higher. As is known, there was a link among the Brazilian caatinga, Amazon, and Mata Atlântica regions that reinforces this hypothesis (Cavalcante 2005). Studies about genetic proximity among $T$. rangeli strains from several geographic regions may collaborate to clarify a possible migratory route that culminated in the establishment of this parasite in Brazilian Northeast. This observation also reinforces the idea that false-positive results of diagnostic tests for T. cruzi infection are possible, as mentionated by Gurgel-Gonçalves et al. (2004).

\section{ACKNOWLEDGMENTS}

To the Secretaria de Estado da Saúde do Ceará for helping us to collect the insects.

\section{REFERENCES}

Bagnoli E 1998. Projeto Araripe - $1^{\text {a }}$ parte: Conhecendo o Araripe: Atividades produtivas da população. Turismo, Ecoturismo, Turismo Cultural e Científico. In Projeto Araripe. [s.i]: [s.n.], p. 292-318.

Barrett TV, Oliveira TS 1977. A Trypanosoma indistinguishable from Trypanosoma rangeli in the haemolymph of Rhodnius domesticus from Brazil. Trans R Soc Trop Med Hyg 71: 445-446.

Cavalcante A 2005. Jardins Suspensos no Sertão, Scientific American Brasil, Duetto Editorial, São Paulo, n. 32, janeiro.

Coura JR, Fernandes O, Arboleda M, Barrett TV, Carrara N, Degrave W, Campbell DA 1996. Human infection by Trypanosoma rangeli in the Brazilian Amazon. Trans $R$ Soc Trop Med Hyg 90: 278-279.

Cuba-Cuba CA 1998. Revisión de los aspectos biológicos y diagnósticos del Trypanosoma (Herpetosoma) rangeli. Rev Soc Bras Med Trop 31: 207-220.

D’Alessandro A 1976. Biology of Trypanosoma (Herpetosoma) rangeli Tejera, 1920. In WHR Lumsden, DA Evans, Biology of Kinetoplastida, vol. 1, Academic Press, London, p. 327-403.

D’Alessandro A, Saraiva NG 1992. Trypanosoma rangeli. In Parasitic Protozoa, 2nd ed., Vol. 2, Academic Press, San Diego, p. 1-54.

D’Alessandro A, Hincapie O 1986. Rhodnius neivai: a new experimental vector of Trypanosoma rangeli. Am J Trop Med Hyg 35: 512-514.

Deane LM 1958. Novo hospedeiro de tripanosomas dos tipos cruzi e rangeli no Estado do Pará. O marsupial Metachirops opossum opossum. Rev Bras Malar Doenças Trop 10: 531-541.
Diotaiuti L, Silveira AC, Elias M, Steindel M 1992. The possibility of occurrence of Trypanosoma rangeli in the state of Tocantins, Brazil. Mem Inst Oswaldo Cruz 87: 451.

Grisard EC, Campbell DA, Romanha AJ 1999. Mini-exon gene sequence polymorphism among Trypanosoma rangeli strains isolated from distinct geographical regions. Parasitology 118: 375-382.

Gurgel-Gonçalves R, Ramalho ED, Duarte MA, Palma ART, Abad-Franch F, Carranza JC, Cuba-Cuba CA 2004. Enzootic transmission of Trypanosoma cruzi and T. rangeli in the Federal District of Brazil. Rev Inst Med Trop São Paulo 46: 323-330.

Lucena DT, Vergetti JG 1973. Infecção natural de Panstrongylus megistus (Burmeister, 1835) por Trypanosoma rangeli (Tejera, 1920), no interior do Estado de Alagoas. Rev Inst Med Trop S Paulo 15: 171-178.

Machado EMM, Alvarenga NJ, Romanha AJ, Grisard EC 2000. A simplified method for sample collection and DNA isolation for polymerase chain reaction detection of Trypanosoma rangeli and Trypanosoma cruzi in triatomine vectors. Mem Inst Oswaldo Cruz 95: 836-866.

Monteiro S, Kaz L 1994. Caatinga - Sertão Sertanejos, Alumbramentos Livroarte, Rio de Janeiro, 255 pp.

Ramirez LE, Lages-Silva E, Alvarenga-Franco F, Matos A, Vargas $\mathrm{N}$, Fernandes O, Zingales B 2002. Abstract high prevalence of Trypanosoma rangeli and Trypanosoma cruzi in opossums and triatomids in a formerly-endemic area of Chagas disease in Southeast Brazil. Acta Trop 84: 189-198.

Souto R, Fernandes O, Macedo A, Campbell D, Zingales B 1996. DNA markers define two major phylogenetics linageages of Trypanosoma cruzi. Mol Biochem Parasitol 83: 141-152.

Steindel M, Carvalho Pinto JC, Toma HK, Mangia HR, RibeiroRodrigues R, Romanha, AJ 1991. Trypanosoma rangeli (Tejera, 1920) isolated from a sylvatic rodent (Echimys dasythrix) in Santa Catarina island, Santa Caratina state: first report of this trypanosome in Southern Brazil. Mem Inst Oswaldo Cruz 86: 73-79.

Steindel M, Dias-Neto E, Carvalho CJ, Grisard E, Menezes C, Murta SM, Simpson AJ, Romanha AJ 1993. Randomly amplified polymorphic DNA (RAPD) and isoenzyme analysis of Trypanosoma rangeli strains. J Euk Microbiol 4: 261-267.

Urdaneta-Morales S, Tejero F 1992. Trypanosoma rangeli (Tejera, 1920): observations upon pleomorphism. Mem Inst Oswaldo Cruz 87: 511-516.

Vallejo GA, Marinkelle CJ, Guhl F, Sánchez N 1988. Comportamiento de la infección y diferenciación morfológica entre Trypanosoma cruzi y $T$ rangeli en el intestino del vector Rhodnius prolixus. Rev Bras Biol 48: 577-587. 
